\title{
The Viscous and Inertial Flow of Air through Perforated Papers *
}

\author{
by Richard R. Baker \\ Research \& Development Centre, $B \cdot A \cdot T(U . K$. and Export) Limited, Southampton, England
}

\section{SUMMARY}

Inherently porous cigarette paper consists of an interlocking network of cellulose fibres interspersed with chalk particles. Spaces in this matrix are of the order of $1 \mu \mathrm{m}$ wide which is small compared to the paper thickness (usually $20 \mu \mathrm{m}$ to $40 \mu \mathrm{m}$ ). However, when cigarette paper is perforated after the paper-making process, e.g. by an electrostatic or mechanical process, the perforation holes are relatively large, usually having mean diameters of the same order of magnitude as the paper thickness.

The total flow of air through perforated cigarette paper thus consists of two components: viscous flow through the porous structure of the paper inherent from the paper-making process, and inertial flow through the perforation holes. Since the air flow/pressure relationships due to these two components of flow differ and since the two components are additive, the total flow through perforated paper may be expressed as:

$$
Q=Z A P+Z^{\prime} A P^{n},
$$

where

$Q$ is the air flow $\left(\mathrm{cm}^{3} \mathrm{~min}^{-1}\right)$,

A is the area of paper $\left(\mathrm{cm}^{2}\right)$ exposed to the flowing air,

$P \quad$ is the pressure difference across the paper (kilopascal),

$Z$ is the base permeability of the paper due to viscous flow through the spaces inherent from the paper-making process (cm $\min ^{-1} \mathrm{kPa}^{-1}$ or COREsTA unit),

\footnotetext{
* Presented at the 9th International Tobacco Science Congress (Conest $A$ ) held in Guangzhou (Canton), China, in 1988.

Received: 27th Ottober 1988 - accepted: 2nd February 1989.
}

$Z^{\prime}$ is the permeability of the paper due to inertial flow through the perforation holes (cm min ${ }^{-1} \mathrm{kPa}^{-1 / a}$ )

and

n is a constant for a given set of perforation holes.

This equation adequately describes gas flow through a variety of perforated cigarette and tipping papers. By using different gases, it is confirmed that $Z$ depends on viscous forces and $Z$ ' depends on inertial forces. By examining the flow of air through a large number of papers with perforation holes of different sizes, it is shown that ' $Z$ ' is dependent on the total area of perforation holes, and that a jet-contraction effect occurs as the air travels through the paper. The parameter $n$ is shown to have a value between 0.5 and 1.0 , and this value is related to mean perforation-hole size.

The permeability of cigarette paper is defined as the flow of air through the paper when the pressure across the paper is 1 kilopascal. Thus from the above equation the "total permeability" of perforated cigarette paper is equal to $Z+Z$.

\section{ZUSAMMENFASSUNG}

In sich poröses Zigarettenpapier besteht aus einem Netzwerk miteinander verketteter und mit Kreidepartikeln durchsetzter Cellulosefasern. Die Zwischenrāume in dieser Matrix haben eine Weite der Größenordnung von $1 \mu \mathrm{m}$ und sind im Vergleich zur Dicke des Papiers (von normalerweise $20 \mu \mathrm{m}$ bis $40 \mu \mathrm{m}$ ) klein. Wird das Papier jedoch, nachdem es angefertigt wurde, beispielsweise durch elektrostatische oder mechanische Verfahren perforiert, sind die Perforationslöcher in ihrem Durchmesser im allgemeinen durchschnittlich von einer Grōßenordnung, die jener der Papierdicke entspricht, und damit verhältnismäßig groß. 
Der gesamte Luftvolumenstrom, der perforiertes Papier passiert, setzt sich somit aus zwei Komponenten zusammen, einerseits nämlich aus der viskosen Luftströmung durch die auf dem Papierherstellungsprozeß beruhende poröse Papierstruktur und andererseits aus der inerten Luftstrōmung durch die Perforationslöcher. $\mathrm{Da}$ das Verhältnis zwischen Luftvolumenstrom und Druckdifferenz dadurch, daß die Strömung aus zwei Komponenten besteht, unterschiedlich sein kann und da sich die Einflußgrößen der beiden Komponenten addieren, läßt sich der gesamte Volumenstrom durch perforiertes Papier in folgender Formel ausdrücken:

$$
Q-Z A P+Z^{\prime} A P^{n},
$$

wobei

Q der Luftrolumenstrom $\left(\mathrm{cm}^{3} \mathrm{~min}^{-1}\right)$ ist,

A die Papierfläche $\left(\mathrm{cm}^{2}\right)$ ist, die tatsächlich von Luft durchströmt wird,

P die Druckdifferenz zwischen Papieroberseite und Papierunterseite ist (Kilopascal),

Z die Grunddurchlässigkeit des Papiers, bedingt durch viskose Strömung durch vom Papierherstellungsprozeß herrūhrende $Z$ wischenräume ( $\mathrm{cm} \min ^{-1} \mathrm{kPa}^{-1}$ oder CORESTA-Einheit),

$Z^{\prime}$ die Durchlässigkeit des Papiers, bedingt durch inerte Strömung durch die Perforationslöcher $\left(\mathrm{cm} \min ^{-1} \mathrm{kPa}^{-1 / a}\right)$

und

n eine Konstante für eine gegebene Anzahl von Perforationslöchern ist.

Die Strōmung von Gasen durch verschiedenartige perforierte Zigaretten- und Mundstücksbelagpapiere wird in dieser Gleichung zutreffend beschrieben. Auch der Einsatz andersartiger Gase ergab eine Bestätigung dafür, daß die Grunddurchlässigkeit $Z$ von viskosen $K$ räften und die Durchlässigkeit $Z^{*}$ von inerten Kräften abhãngig ist. Die Untersuchung der Luftstrōmung bei einer großen Zahl unterschiedlich perforierter Papiere zeigte, daß die Durchlässigkeit $Z$ ' von der Gesamtfläche aller Perforationslöcher abhăngig ist und daß Luft das Papier unter Strahleinschnürung durchdringt. Der Parameter $n$ belief sich nach diesen Untersuchungen auf einen Wert $\mathrm{zw}$ wischen 0.5 und 1.0, wobei eine Beziehung zur durchschnittlichen Größe der Perforationslöcher bestand.

Die Durchlässigkeit von Zigarettenpapier wird als Luftstrōmung definiert, die das Papier bei einer Druckdifferenz von $1 \mathrm{kPa}$ durchdringt. Aufgrund der hier entwikkelten Gleichung entspricht die „Gesamtdurchlässigkeit" von perforiertem Zigarettenpapier dem Wert Z + $\mathrm{Z}^{\prime}$.

\section{RESUME}

Le papier à cigarette naturellement poreux se compose d'un réseau enchevêtré de fibres de cellulose entremêlés de particules de craie. Les espaces de cette matrice sont de l'ordre de $1 \mu \mathrm{m}$, ce qui est peu par comparaison aux épaisseurs du papier (en gênéral, de 20 à $40 \mu \mathrm{m}$ ). Mais lorsque le papier à cigarette est perforé après le processus de fabrication du papier, c.à.d. par un procédé électrostatique ou mécanique, les trous de perforation sont assez grands et présentent en général des diamètres moyens du même ordre de grandeur que l'êpaisseur du papier.

Le flux total de l'air traversant le papier à cigarette perforê se compose donc de deux éléments: un flux visqueux traversant la structure poreuse propre au papier qui est inhérente au processus de fabrication du papier, et un flux inertiel traversant les trous de perforation. Comme les rapports flux d'air/pression dûs à ces deux composants du flux sont différents l'un de l'autre et que ces deux composants sont additifs, le flux total traversant le papier perforé peut donc être exprimé selon la formule:

$$
Q=Z A P+Z^{\prime} A P^{n},
$$

dans laquelle

$Q$ est le flux d'air (en $\left.\mathrm{cm}^{3} \mathrm{~min}^{-1}\right)$,

A est la surface du papier (en $\mathrm{cm}^{2}$ ) exposée au flux d'air,

P est la différence de pression sur l'ensemble du papier (en kilopascal),

Z est la perméabilité de base du papier due au flux visqueux traversant les espaces inhérents au processus de fabrication du papier $\left(\mathrm{cm} \mathrm{min}{ }^{-1} \mathrm{kPa}^{-1}\right.$ ou unité CORESTA),

$Z^{\prime}$ est la perméabilité du papier due au flux inertiel dans les trous de perforation $\left(\mathrm{cm} \mathrm{min}^{-1} \mathrm{kPa}^{-1 / 1}\right.$ )

et

n est une constante correspondant à un ensemble donné de trous de perforation.

Cette équation décrit de façon satisfaisante le flux des gaz dans divers papiers à cigarette et papiers manchette perforés. L'utilisation de différents gaz a permis de confirmer que $Z$ dépend des forces visqueuses et $Z$ ' des forces inertielles. En étudiant le flux de l'air traversant un grand nombre de papiers présentant des perforations de diverses dimensions, on a démontré que $Z$ ' dépend de la surface totale des trous de perforation et que l'effet de contraction du jet se produit lorsque l'air traverse le papier. On a constaté que le paramètre $n$ a une valeur comprise entre 0,5 et 1,0 et que cette valeur est fonction de la dimension moyenne des perforations.

La perméabilité du papier à cigarette est définie comme étant le flux d'air traversant le papier lorsque la pression à travers le papier est de 1 kilopascal. D'après l'équation ci-dessus, la "perméabilité totale* du papier a cigarette perforé est donc égale à $Z+Z$ ' 


\section{INTRODUCTION}

Ventilation through both the filter and cigarette paper is one of the principal methods by which the levels of all mainstream components can be reduced. Calculation of the dilution flows through both the filter-tipping paper and cigarette paper requires knowledge of the relationship between the air flow and pressure differential through the various types of paper used in the construction of cigarettes. It is well known that the relationship between air flow and pressure is linear through inherently porous and relatively low-permeability paper, and non-linear through perforated and high-permeability plug-wrap papers (e.g. 1-8). In fact the corESTA method for measuring paper permeability (9) recommends measuring the air flow through perforated paper at two pressures ( 1 and 0.25 kilopascal) to obtain an indication of the non-linearity.

The objectives of the present study were to present and test an equation which describes the air-flow relationships through all types of papers, and to relate terms in the equation to characteristics of the paper.

\section{EQUATIONS OF PAPER PERMEABILITY}

SELKE and Mathews (5) have used equation 1 to describe the relationship between air flow $Q\left(\mathrm{~cm}^{3} \mathrm{~min}^{-1}\right)$ and pressure differential $P$ ( $\mathrm{cm}$ w.g.) across the paper:

$$
\mathrm{Q}=\mathbf{k} \mathrm{Pa}^{\mathrm{a}},
$$

where $k$ and $n$ are constants. They have shown that $n$ has a value of 1.0 for a naturally porous paper, 0.7 for electrically perforated cigarette papers, $0.6-0.7$ for plug-wrap papers, and $0.5-0.7$ for perforated tipping papers.

It is not possible with equation 1 to separate the components of permeability due to the natural pores and the larger perforations in perforated or highly porous papers. Owens (6) has presented a quadratic type equation which has additive components of viscous flow through the natural pores and inertial flow through the perforations, although he has not given any results with his equation. Matris (8) has used a similar equation to describe the pressure drop across plug-wrap and tipping papers and shown that, statistically, it gives an equally good fit to experimental data as equation 1.

Inherently porous cigarette paper consists of an interlocking network of cellulose fibres interspersed with chalk particles and spaces in this matrix are of the order of $1 \mu \mathrm{m}$ wide. This is small compared to the paper thickness (usually $20 \mu \mathrm{m}$ to $40 \mu \mathrm{m}$ ), and the Reynolds number in these spaces for typical cigarette flows is much less than unity. Thus the flow of air through these spaces in the paper is governed by viscous forces. However, when cigarette paper is perforated after the paper-making process, e.g. by an electrostatic or mechanical process, the perforation holes are relatively large, usually having mean diameters of the same order of magnitude as the paper thickness. The Reynolds number for typical cigarette flows is $20-200$ and so the flow of air through these large holes is governed by inertial forces. It is emphasized that the flow is still laminar under these conditions; it is not turbulent as has been erroneously stated in the past (e.g. (2)).

The total flow through perforated cigarette paper thus consists of two components: viscous flow through the porous structure of the paper inherent from the papermaking process, and inertial flow through the perforation holes. Since the air flow/pressure relationships due to these two components of flow differ and since the two components are additive, the total flow through perforated paper may be expressed as:

$$
Q=Z A P+Z A P^{n},
$$

where

$Q$ is the air flow $\left(\mathrm{cm}^{3} \mathrm{~min}^{-1}\right)$,

A is the arez of paper $\left(\mathrm{cm}^{2}\right)$ exposed to the flowing air,

$P \quad$ is the pressure difference across the paper (kilopascal) ${ }^{*}$,

$Z \quad$ is the base permeability of the paper due to viscous flow through the spaces inherent from the paper-making process (cm $\min ^{-1} \mathrm{kPa}^{-1}$ or COREsts unit),

$Z^{\prime}$ is the permeability of the paper due to inertial flow through the perforation holes $\left(\mathrm{cm} \mathrm{min}{ }^{-1} \mathrm{kPa}^{-1 / a}\right.$ )

and

$\mathrm{n}$ is a constant for a given set of perforation holes $(0.5 \leq n \leq 1.0)$. The exact value of $n$ depends on the size of the perforation holes in the paper.

The permeability of cigarette paper measured by the corrsta method (9) is defined as the flow of air through the paper when the pressure across the paper is 1 kilopascal. Thus from the above equation the "total permeability of perforated cigarette paper is equal to $Z$ $+Z^{\prime}$.

In a previous study (4), a simple model was presented in which inherently porous paper was treated as a bundle of parallel, circular cross-section, capillary tubes. The flow through each tube was governed by Poiseuille's law of viscous flow, and it was shown that, converting to units used in the corEsTa method, the permeability due to viscous forces is given by:

$$
Z=\frac{\pi j r^{4}}{\eta L} 7.4 \times 10^{4},
$$

where

$\eta \quad$ is the viscosity of the fluid (air)

flowing through the paper (poise, i.e. $\mathrm{g} \mathrm{cm}^{-1} \mathrm{~s}^{-1}$ ),

$\overline{* 1 \text { kilopaseal }}=1 \mathrm{cbar}-980 \mathrm{Nm}^{-2}=10 \mathrm{~cm}$ w.g. 
L is the paper thickness (cm),

assumed to be equal to the tortuous length

of the formal pores,

and

$j$ is the number of formal pores of

mean radius $\mathrm{r}(\mathrm{cm})$ per $\mathrm{cm}^{2}$ of paper.

In mechanically, electrostatically or laser perforated papers, the perforation holes have sizes comparable to the paper thickness. These holes act as nozzles to the air flow and Bernoulli's theorem for frictionless flow can be applied to each nozzle. It can be shown that the permeability due to flow through large perforation holes in the paper is given by:

$$
Z^{\prime}=\frac{a j a}{\sqrt{\varrho}} 8.3 \times 10^{3},
$$

where

$\alpha \quad$ is the coefficient of contraction

as the flow exits from the nozzle,

e is the density of the flowing fluid $\left(\mathrm{g} \mathrm{cm}^{-3}\right)$

and

j is the number of perforation holes of

mean area a $\left(\mathrm{cm}^{2}\right)$ per $\mathrm{cm}^{2}$ of paper.

Bernoulli's equation, in which flow rate is proportional to $\sqrt{\mathrm{P}}$, strictly only applies to a discharge nozzle where the flow is completely dominated by inertial forces. With perforated cigarette paper the holes are actually more than simple nozzles and do have a finite length in which some viscous forces can contribute to the flow. Consequently, in the empirical equation 2 above, a $\mathrm{P}^{\mathrm{n}}$ term appears and, as is shown below, $\mathrm{n}$ only approaches 0.5 for very large perforation holes (which act as pure nozzles).

\section{EXPERIMENTAL DETAILS}

A variety of perforated cigarette and tipping papers were obtained from various paper manufacturers in $\mathrm{Eu}$ rope and the U.S.A. In addition, some papers were electrostatically perforated in the laboratory using a specially constructed apparatus.

\section{Determination of Flow/Pressure Relationships}

The flow of air through perforated cigarette and tipping papers at a series of pressures across the paper between $1 \mathrm{~cm}$ and $32 \mathrm{~cm}$ w.g. has been measured using a permeability meter designed and built at $B \cdot A \cdot T(10)$ and conforming to the coresta procedures (9).

In one series of experiments, the flow/pressure relationship with other gases was also determined: hydrogen, helium, neon, argon and sulphur hexafluoride. The flow meters on the permeability meter were calibrated for each of these gases using bubble meters. During these experiments, the paper-mounting head of the permeability meter was surrounded by a chamber containing the appropriate gas at atmospheric pressure. This eliminated potential problems of diffusion between the gas flowing through the paper and the surrounding air.

\section{Determination of Perforation-Hole Size Distribution}

The perforation-hole size distribution in the paper was obtained by measuring the size of one hundred perforation holes in the paper, using photographs of the holes taken through an optical microscope.

\section{RESULTS AND DISCUSSION}

\section{Pressure/Flow Relationships}

Figure 1 gives the experimental data of air flow and pressure for three electrostatically perforated papers. For each paper, the flow/pressure data have been regressed by equation 2, and estimates of the three unknown parameters in the equation made ( $Z, Z^{\prime}$ and $n$ ). In practice it is not possible to obtain unique values of three parameters from the regression. Consequently, values of the known base permeability of the papers $(Z)$ were inserted into the equation, so that only two parameters $\left(Z^{\prime}\right.$ and $\left.n\right)$ were estimated from the regressions. As far as was practicable, the base permeabilities of the papers were measured on samples of the paper obtained prior to perforation.

Also shown in Figure 1 are the flow/pressure relationships obtained from equation 2 using the values of $Z$, $\mathrm{Z}^{\prime}$ and $\mathbf{n}$ for the paper. Clearly, the equation adequately describes the experimental flow/pressure data. It should be noted that equation 1 and the quadratic equation of Mathis (8) give equally good fits to the data. Equation 2 only is used in the analysis in this report, because of the ease in relating its terms to characteristics of the paper.

\section{Effect of Different Gases on Permeability Parameters}

Equations 3 and 4 above predict that:

base permeability $\mathrm{Z}$ is proportional to 1 / gas viscosity

and

$Z^{\prime}$ is proportional to $1 / \sqrt{\text { gas density }}$. 
The base permeabilities of two unperforated, naturally porous papers with air permeabilities of 11 and 85 coRESTA units have been measured with different gases flowing through them. The variation with $1 /$ viscosity, shown in Figure 2, is linear as predicted. The scatter on the plots indicates the over-simplifications in the discrete-pore model of paper. From the gradient of the plots, the formed values of $\mathrm{j} \mathrm{r}^{4}$ for the low and high-permeability papers are $4 \times 10^{-11} \mathrm{~cm}^{2}$ and $3 \times$ $10^{-10} \mathrm{~cm}^{2}$, respectively.

Similarly, the inertial permeabilities $\left(Z^{\prime}\right)$ of three electrostatically perforated papers have been measured with different gases flowing through them, and the variation

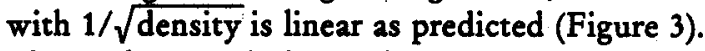

The perforation holes in these papers had mean radii of $33 \mu \mathrm{m}$ to $43 \mu \mathrm{m}$. By measuring the gradients of the lines in Figure 3 and using the known perforation-hole dimensions and number (Table 1), the contraction coefficient for the holes can be calculated from equation 4 . The values obtained are in the range of 0.082 to 0.42 (Table 1) and are commented on in the next section.

\section{Effect of Perforation-Hole Size Characteristics on Permeability Parameters}

Equation 4 predicts that $Z^{\prime}$ should be linearly related to $\mathrm{ja}$, the total area of the perforation holes per $\mathrm{cm}^{2}$ of paper. This relationship is seen to be obeyed for both perforated cigarette papers (Figure 4, correlation coefficient: 0.94) and perforated tipping papers * (Figure 5, correlation coefficient: 0.97 ). Figure 5 also includes data obtained for different shaped perforation holes, and it is seen that there is no systematic effect of shape.

From the gradients of the plots in Figures 4 and 5, values of the contraction coefficient $(\alpha)$ of 0.25 and 0.66 for the cigarette and tipping papers, respectively, are calculated.

For tipping paper, the value of $\alpha$ is very close to the value of $0.61-0.64$ quoted in the fluid-dynamics literature for flow through nozzles (11). Tipping papers in general have sharp-edged holes of fairly uniform size and shape, whose hydraulic diameter is usually larger than the paper thickness. Such holes act simply as nozzles. On the other hand, perforated cigarette papers have holes with ill-defined edges, often with cellulose fibres across the hole, and a significant proportion of the holes in any given paper have diameters smaller than their length.

In Figure 6, the values of $n$ obtained for each perforated paper from the flow/pressure regression of equation 2 are plotted against the average diameter of the perforation hole. Also included in the plot are the values obtained with a series of six Nuclepore mem-

\footnotetext{
* The flow measurements for perforated tipping papers were carried out with $1 \mathrm{~cm}^{2}$ of paper exposed to the air flow, as recommended by corzsta (9). It was also made certain that a $1.0 \mathrm{~cm}$ length of the perforation line was included in the exposed area.
}

Figure 1.

Experimental and regression relationships between alr flow $(Q)$ and pressure $(P)$ for three electrostatically perforated clgarette papers [area (A): $10 \mathrm{~cm}^{2}$ ].

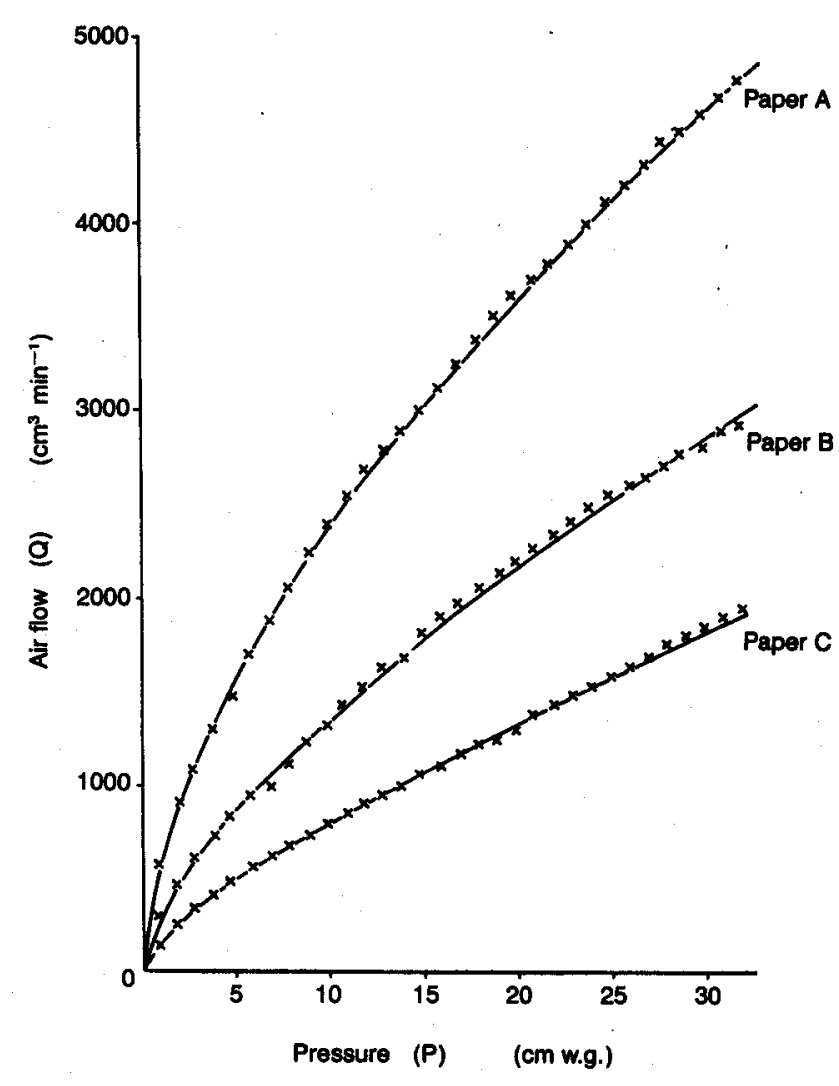

Predicted by equation 2:
Experimental point:

Figure 2.

Base (viscous) permeablity of naturally porous papers as function of 1/viscosity of flowing gas.

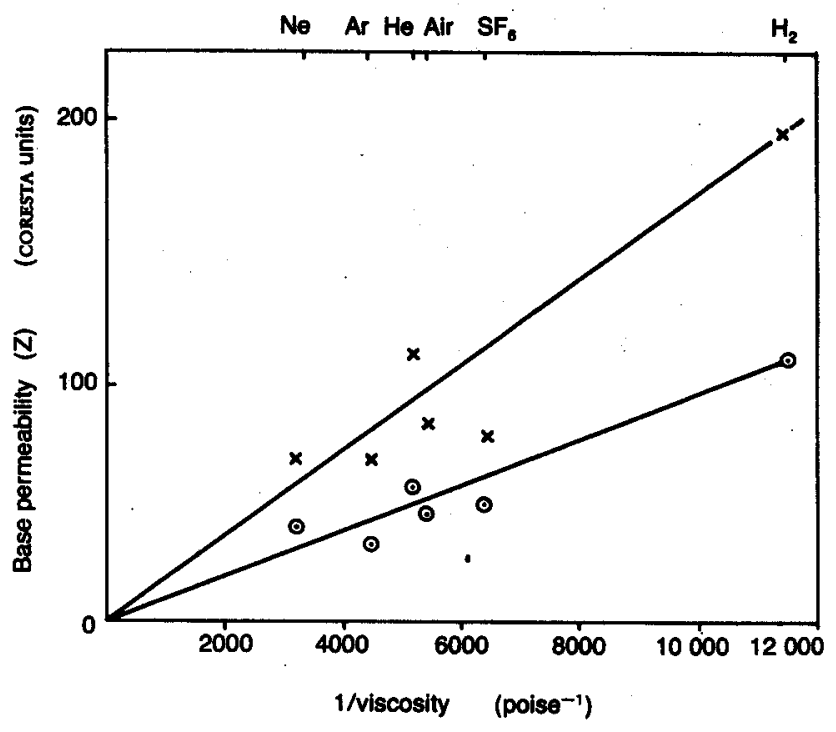

Paper 1: $\times \quad$ Paper 2: $\odot$

(4 times Z) 
Figure 3.

Inertial permeability of electrostatically perforated papers as function of $1 / \sqrt{\text { density }}$ of flowing gas.

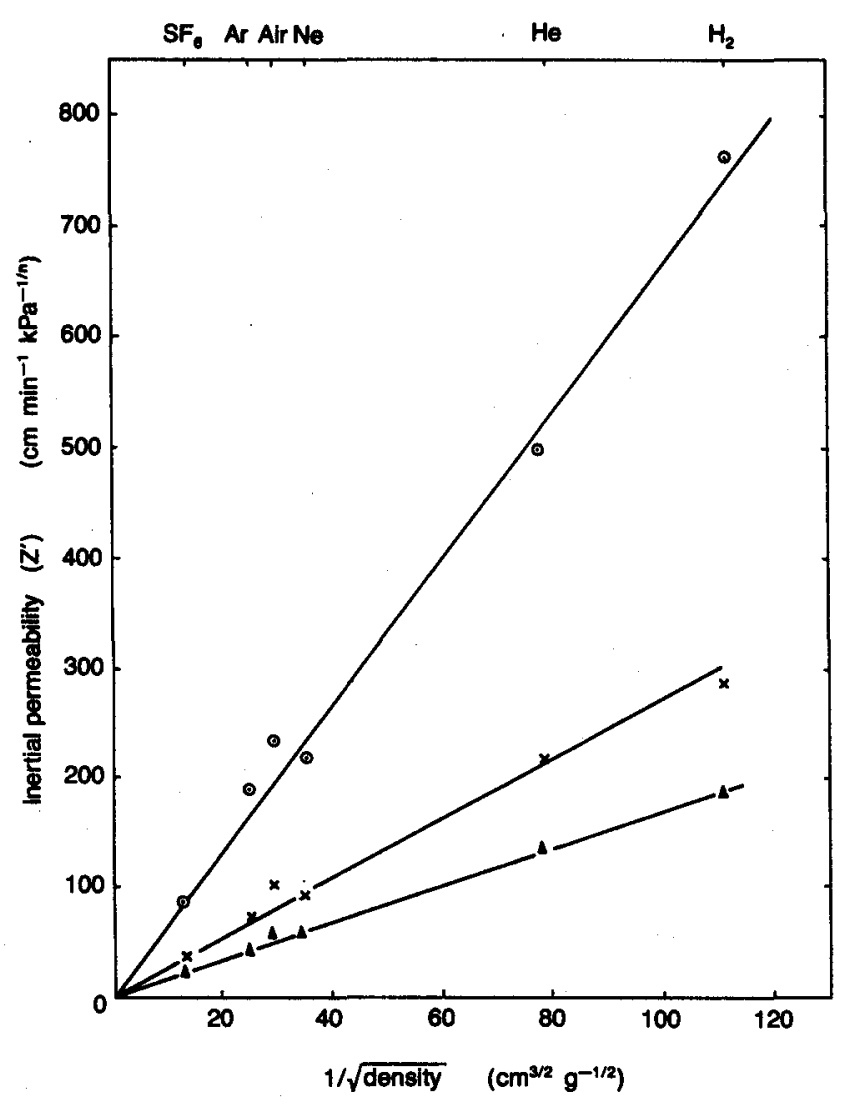

Paper 1: $\odot \quad$ Paper 2: $x \quad$ Paper 3: $\Delta$

Square-shape hole:

Oblong-shape hole:

Circular-shape hole:

Oval-shape hole:
Figure 4.

Inertial permeablilty of perforated cigarette papers as functlon of total area of perforation holes.

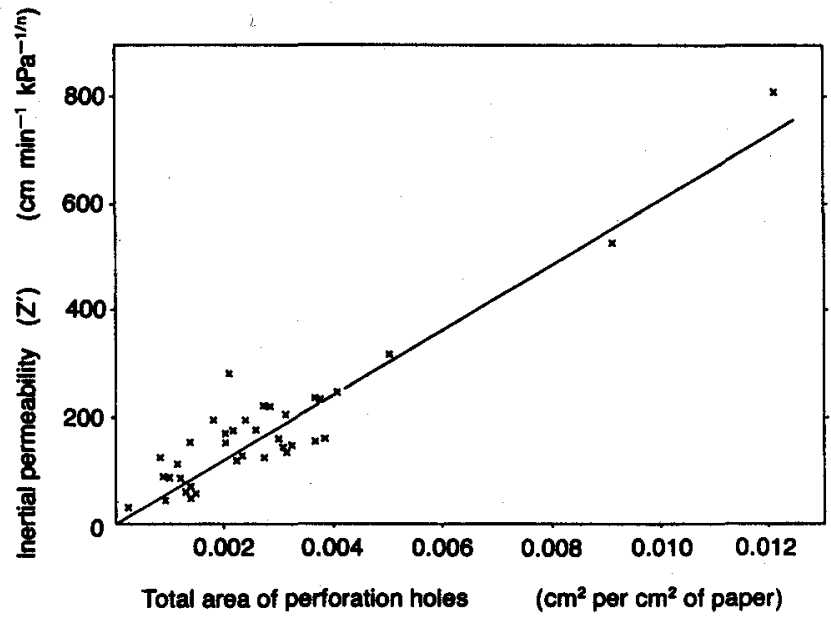

Figure 5.

Inertial permeablity of perforated tipping papers as function of total area of perforation holes.

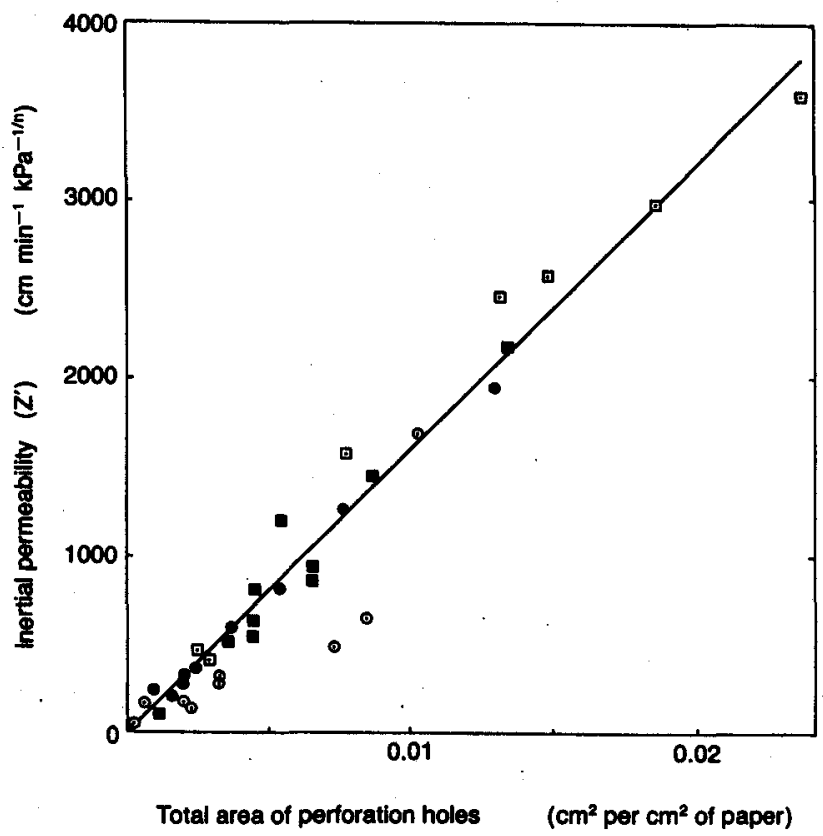

Table 1

Characterlatics of some electrostatically perforated papers.

\begin{tabular}{|c|c|c|c|c|c|}
\hline \multirow[b]{2}{*}{ Paper } & \multirow[b]{2}{*}{$\begin{array}{c}\text { Base } \\
\text { permeability } \\
\text { (coresta unit) }\end{array}$} & \multicolumn{2}{|c|}{ Perforation holes } & \multirow[b]{2}{*}{$\begin{array}{c}\text { Paper } \\
\text { thickness } \\
\text { ( } \mu \mathrm{m})\end{array}$} & \multirow[b]{2}{*}{$\begin{array}{c}\text { Calculated } \\
\text { contraction } \\
\text { coefficient } \\
{[\alpha]}\end{array}$} \\
\hline & & $\begin{array}{c}\text { Number } \\
\text { per cm } \\
{[j]}\end{array}$ & $\begin{array}{c}\text { Mean } \\
\text { radius } \\
{[\mathrm{r}]} \\
(\mu \mathrm{m})\end{array}$ & & \\
\hline 1 & 82 & 54 & 33 & 37 & 0.42 \\
\hline 2 & 12 & 50 & 43 & 34 & 0.10 \\
\hline 3 & 12 & 51 & 38 & 34 & 0.082 \\
\hline
\end{tabular}


Figure 6.

Perforated clgarette paper: $\mathbf{n}$ as function of average perforation-hole dlameter.

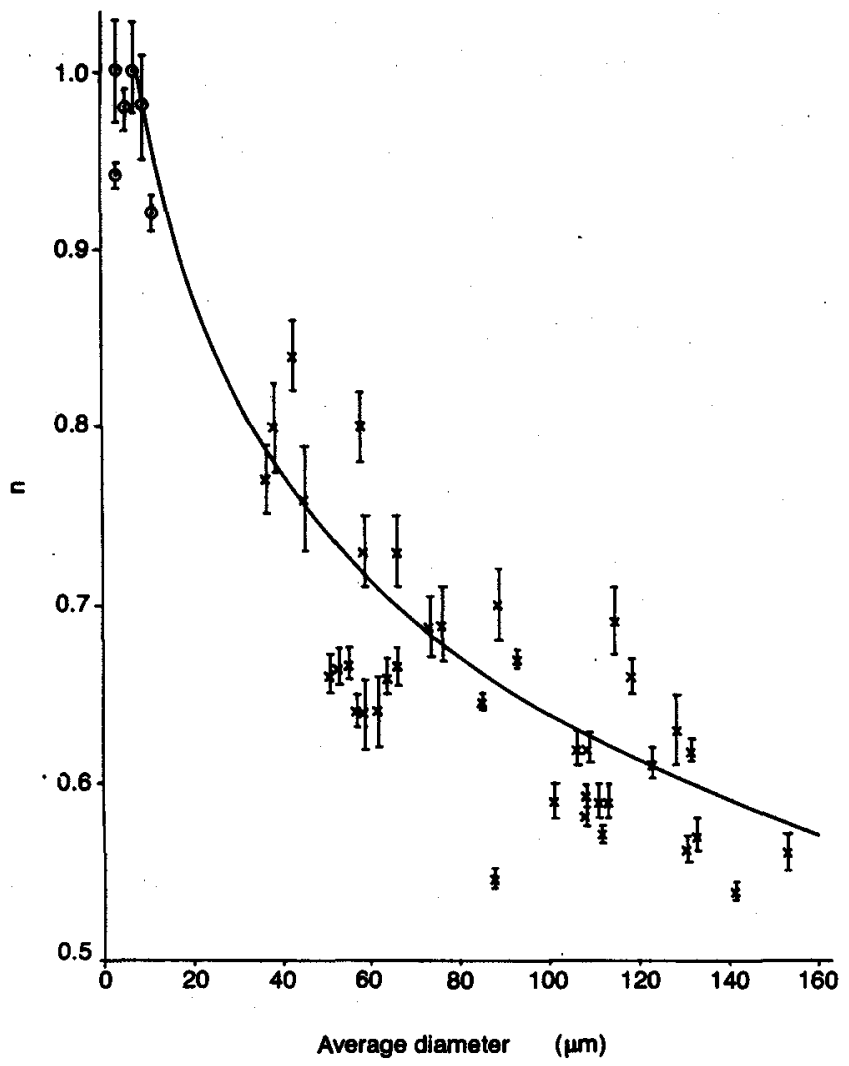

Nuclepore membrane: $\odot$. Cigarette paper: $x$

branes*. These membranes were $10 \mu \mathrm{m}$ thick and had relatively small holes, in the range of $3 \mu \mathrm{m}$ to $10 \mu \mathrm{m}$ mean diameter and a number density of $1.4 \times 10^{5}$ to $2.1 \times 10^{6}$ holes per $\mathrm{cm}^{2}$. Inclusion of these membranes extends the range of hole diameters. A similar plot for n obtained for perforated tipping papers is shown in Figure 7.

For small perforation holes ( $<8 \mu \mathrm{m}$ diameter) the value of $\mathbf{n}$ is equal to 1.0. Holes of these sizes in cigarette paper are acting as capillary tubes and not nozzles, and the flow through them is dominated by viscous forces. The value of $\mathbf{n}$ falls as the hole size increases and the flow through the hole acts more like a nozzle. For large holes ( $>280 \mu \mathrm{m}$ hydraulic diameter) $\mathrm{n}$ is equal to 0.5 .

A regression of the data in Figure 6 shows that $n$ is related to the mean radius $r(\mu \mathrm{m})$ of the perforation hole in cigarette paper by the following equation:

$$
\mathrm{n}=1.22-0.148 \ln \mathrm{r}
$$

\footnotetext{
* The Nuclepore membrane is made from 2 sheet of polycarbonate plastic by the Nuclepore Corporation, Pleasanton, Californiz. The film is exposed to a collimated beam of fission fragments in a nuclear reactor. As the particles pass through the material they leave sensitized tracks, which are developed into uniform, cylindrical pores in an etching bath. The pore size is controlled by the length of the etching process, while the pore density is controlled by the residence time in the nuclear reactor.
}

Figure 7.

Perforated tipping paper: $\mathbf{n}$ as function of hydraullc diameter of pertoration hole.

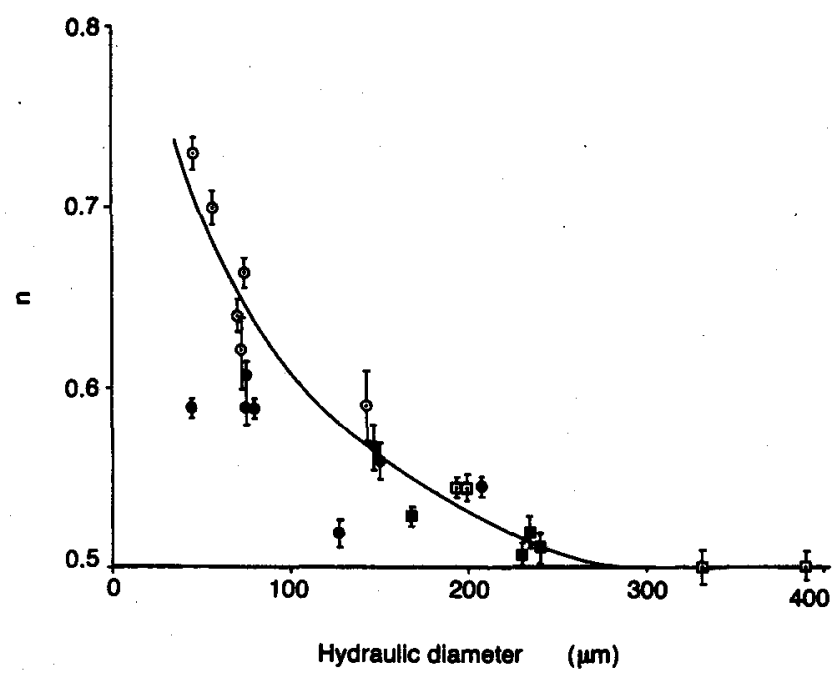

Square-shape hole: $\square$ Circular-shape hole: $\odot$ Oblong-shape hole: $\quad$ Oval-shape hole:

with the boundary conditions of $1.0 \geq n \geq 0.5$.

Similarly, the data in Figure 7 are described by the following regression:

$$
\mathrm{n}=1.49 \mathrm{~d}^{-0.194}
$$

with the same boundary conditions, where $d$ is the mean hydraulic diameter of the perforation hole $(\mu \mathrm{m})$, equal to 4 times area of cross-section per perimeter.

\section{REFERENCES}

1. Lipp, G.: Zum Problem vergleichender Untersuchungen an porösen und perforierten Cigarettenpapieren (On the problem of comparative investigations of porous and perforated cigarette paper); Beitr. Tabakforsch. 3 (1966) 477-483.

2. Butters, D.: Measurement of paper porosity; Beitr. Tabakforsch. 5 (1970) 307-311 and 6 (1972) 165.

3. Mattina, C. F., and W. A. Selke: Influence of the paper on the smoke of cigarettes; Proc. Am. Chem. Soc. Symp., 173rd Am. Chem. Soc. Agric. \& Food Chem. Div. meeting on Recent advances in the chemical composition of tobacco and tobacco smoke, New Orleans, Louisiana, 1977, pp. 533552.

4. Baker, R. R., and R. A. Crellin: The diffusion of carbon monoxide out of cigarettes; Beitr. Tabakforsch. 9 (1977) 131-140.

5. Selke, W. A., and J. H. Mathews: The permeability of cigarette papers and cigarette ventilation; Beitr. Tabakforsch. Int. 9 (1978) 193-200. 
6. Owens, W. F., Jr.: Effect of cigarette paper on smoke yield and composition; Recent Adv. Tob. Sci. 4 (1978) 3-34.

7. DeLucia, M. L, C. F. Mattina and W. A. Selke: Physical parameters that affect composition of smoke; Recent Adv. Tob. Sci. 6 (1980) 225-238.

8. Mathis, D. E.: Flow rate dependence of ventilation; Beitr. Tabakforsch. Int. 14 (1987) 11-19.

9. CORESta Recommended Method No. 3: Determination of the air permeability of cigarette paper; CORESTA Information Bulletin 1975-3/4, 38-41.

10. Baker, R. R., and B. G. Bunn: Measuring permeability of paper; (a) U.K. Patent No. 2,001,444 and (b) U.S. Patent No. 4,191,046.
11. Prandtl, L.: Essentials of fluid dynamics (English translation); Blackie and Son Ltd., London and Glasgow, 1952, p. 43.

Autbor's address:

$B \cdot A \cdot T$ (U.K. and Export) Limited, Research \& Development Centre,

Regent's Park Road,

Southampton, SO9 IPE,

England. 